\title{
Environmental Hazard Effects on Agricultural Production among Rural Households in Imo State, Nigeria
}

\author{
Izuogu C.U \\ Department of Rural Sociology and Extension, Michael Okpara University of Agriculture, Abia State
}

Copyright (C) 2015 by authors, all rights reserved. Authors agree that this article remains permanently open access under the terms of the Creative Commons Attribution License 4.0 International License

\begin{abstract}
This study evaluated environmental hazard effects as a critical issue relating to agricultural production of rural households in Imo State, Nigeria. Multi- staged purposive and random sampling techniques were used to choose the samples. The study determined the farming activities of the respondents, ascertained the respondents knowledge of the effects of environmental hazard on agricultural production among respondents and analysed the relationship between environmental hazard and agricultural production of respondents. Primary data collected from 116 respondents were used for the study. Data analysis was carried out with the use of descriptive statistics and multiple regression analysis. Results from the study show that majority $(76.54 \%)$ of the respondents were engaged in cassava production as their major cash crop. A mean score of 2.18 on a three point likert-liked scale showed that majority of the respondents were aware of the effects of environmental hazard on their agricultural production. Results from the regression analysis shows that flood, oil pollution, erosion and wind storm were significant and negatively related to the agricultural production. Oil explorations that go on in the rural areas should be adequately monitored to reduce its negative effect on the rural environment. It was therefore recommended that more efforts should be made to mitigate the effects of environmental hazard on agricultural production of rural dwellers. This could be achieved by providing agricultural insurance schemes for farmers, paying compensation to farmers over losses arising from environmental hazards.
\end{abstract}

Keywords Environmental Hazard, Rural Households, Agricultural Production

\section{Introduction}

Human beings began to alter the earth's environment to eke out existence thousands of years ago. First, it was through the use of simple tools for hunting and gathering, and later with more complex tools for land cultivation (for planting purposes) and rearing of animals. All over the world, evidence abounds of human intervention and disturbance of environmental stability. Although environmental variability is a natural phenomenon, the increasing frequency and severity of extreme climatic events can in part be attributed to human activities such as deforestation and inappropriate management of land and water resources ${ }^{1}$

Human-caused hazards may be intentional, such as the illegal discharge of oil, or accidental such as toxic spills or nuclear meltdown ${ }^{2}$. The distinction between natural and human-made hazards is becoming blurred. Human-made hazards, such as technological and chemical accidents, air and water pollution and desertification, degrade the environment and can lead to disaster ${ }^{3}$. Hazards once considered natural and unavoidable are now thought to be partly due to human-induced environmental change. For example, research shows that in many parts of the world, an increase in flooding is linked to the escalating rate of deforestation in those areas.

Climate models predict that climate change will lead to, among other things, an increase in unpredictability of rainfall, warmer temperatures, and an increase in the severity and frequency of extreme weather events. These changes are expected to decrease agricultural productivity in the developing world by $10 \%$ to $20 \%$ over the next 40 years. Subsistence farmers in the developing world find it particularly difficult to cope with such climate-related hazards, as they do not have the capital to invest in new adaptive practices with which to protect their homes and families. Especially sensitive to climatic changes are those households that rely almost entirely on rain-fed agriculture for their livelihoods. There has been a recent focus in the international development community and literature on strategies to help subsistence farmers reduce their vulnerability to climate change ${ }^{4}$ 
Environmental education increases public awareness and knowledge about environmental issues or problems. In doing so, it provides the public with the necessary skills to make informed decisions and take responsible action. Studying the environment involves two basic approaches. The first approach, based on the fact that humans share this planet with other living creatures, focuses on the interactions among living systems. The second broader approach looks at the total environment, and emphasizes that all the planet's resources, both living and non-living, are ultimately limited. With both approaches, however, the human species is the central player, because human welfare and activities are foremost in our attention ${ }^{5}$

\section{Objectives of the Study}

The broad objective of the study was to evaluate environmental hazard effects as a critical issue affecting agricultural production among rural households in Imo State, Nigeria. Specifically, the study:

i) examined the farming enterprises of the respondents

ii) ascertained respondent's perception on the effect of environmental hazards on their agricultural resources

iii) examined the relationship between environmental hazard and agricultural production in the study area.

\section{Methodology}

This study was carried out in Imo State. The state is located within the rainforest belt of Nigeria, and the temperature ranges between $200 \mathrm{C}$ and $300 \mathrm{C}$. It is characterized by the dust-laden north easterly winds, which blow across the country during the dry season (Mid October to March) ${ }^{6}$. Agriculture is the major occupation of the people. The major food produce include cassava, yam, cocoyam, maize, and melon. Cash crops produced in Imo State include oil palm and rubber ${ }^{7}$. Economic trees like the iroko, mahogany, obeche, gmelina, bamboo, rubber and oil palm predominate. Due to high population density, most parts of the State have been so farmed and degraded that the original vegetation has disappeared. Farmers are thus forced into marginal lands, a situation aggravated by the rising demand for fuel wood $^{8}$. The population for this study comprised of all rural households in Imo State. The sampling frame comprised of rural households in some selected rural communities within the three agricultural zones of the state. Multistage sampling procedure involving purposive and random sampling techniques were used for the study. The first stage was the purposive selection rural households in Okigwe, Orlu and Owerri zones of Imo State Nigeria. This is because these are the three Agricultural zones within the state.

At the second stage, two Local Government Areas were selected from each zone. In Orlu zone, Ohaji-Egbema and Oguta LGAs was purposively selected while two L.G.As was randomly selected from each of Okigwe and Owerri zones. The purposive selection of Ohaji-Egbema and Oguta was as a result of the researchers' familiarity with the area and high incidence of environmental hazard emanating from gas flaring, flooding, erosion, and bush fire incidents etc. The third stage of the sampling was the random selection of farmers in two rural communities in each of the selected LGAs in Okigwe and Owerri, while Izombe and Oguta communities was purposively selected from Oguta LGA; Egbema and Ohaji communities was purposively selected from Ohaji-Egbema L.G.A. This as a result of evidence of environmental hazard in these communities

The fourth stage was the random selection of 10 farmers from each of the twelve autonomous communities which gave a sample size of 120 respondents. At the collection of questionnaires, only 116 respondents returned valid research questionnaires.

\section{Data Collection and Analysis}

Data were generated from both primary and secondary sources. The primary data were collected with questionnaire, interview schedule, and field observation. While secondary data were obtained from literature in form of textbooks, journal, annual reviews, internet, and electronic libraries.

Data were analysed using descriptive and inferential statistics such as frequency distribution, percentage, mean, analysis of variance and regression.

\section{Results and Discussion}

\section{Farming enterprise of respondents}

Table 1 shows that $76.54 \%$ of the respondents, were engaged in cassava production as their major food and cash crop while over 63 per cent were engaged in maize production, and forty three per cent engaged in yam production. The Table shows that $35.8 \%$ and $29 \%$ of respondents cultivated melon and cocoyam respectively. The increase in cassava production could be attributed to the fact that cassava as a staple crop has featured prominently in mixed and multiple intercropping farming systems of Imo State; and the cassava chain options are numerous, including cake, biscuits, chin-chin, flakes and croquettes ${ }^{9}$. Also, the effort of the Nigerian government in facilitating the development of new disease-resistant cassava varieties by the joint efforts of IITA, National Root Crops Research Institute (NRCRI), Root and Tuber Expansion Program (RTEP) which has brought about an increase in farmer's income thereby making it more attractive ${ }^{10}$ is also quite commendable. Echebiri and Edaba ${ }^{11}$ had observed that the production of cassava is concentrated in the hands of numerous smallholder farmers located primarily in the south and central regions of Nigeria. 
Table 1. Major crops grown by respondents $(\mathrm{N}=116)$

\begin{tabular}{ccc}
\hline Crop & Frequency & Percentage \\
Cassava & $114^{*}$ & 98.27 \\
Cocoyam & $47^{*}$ & 40.52 \\
Maize & $103^{*}$ & 88.79 \\
Melon & $58^{*}$ & 0.50 \\
Yam & $69^{*}$ & 59.48 \\
& Animal & \\
Sheep/Goat & $34^{*}$ & 29.31 \\
Fishery & $12^{*}$ & 10.34 \\
Poultry & $87^{*}$ & 75.0 \\
Rabbitry & $4^{*}$ & 3.44 \\
\hline
\end{tabular}

Source: Field Survey.

*Multiple Responses

As shown on Table 1, some of the respondents were engaged in different forms of animal production. Seventy five percent of the respondents were engaged in poultry production, $29.31 \%$ in sheep and goat production, and $10.34 \%$ in fishery production. Mixed farming offers highest return on farm business, as the by-products of the farm are properly utilized. Mixed farming also provides for efficient utilization of land, labour, equipment and other resources.

2. Effect of environmental hazards on agricultural production

Table 2 shows the respondent's perception on the effect of environmental hazards on their agricultural resources. The respondents were aware of the perceived effects of environmental hazard on their crop and livestock resources as well as other farm activities $(\mathrm{X}=2.18)$

This is in agreement with a priori expectations. Some of the respondents who were victims were still having fresh memories of the losses they encountered from the devastating flood that affected many parts of Imo state in

Table 2. Respondent's perception of the effect of environmental hazard on their agricultural resources $(\mathrm{N}=116)$

\begin{tabular}{|c|c|c|c|c|c|}
\hline & Item & Agreed & Undecided & Disagreed & $X$ \\
\hline 1 & Loss in weight of livestock & $113 *(76.88)$ & $1 *(0.62)$ & $36^{*}(22.50)$ & 2.54 \\
\hline 2 & Reduces farm output & $112 *(77.22)$ & $8 *(5.06)$ & $28 *(17.72)$ & 2.59 \\
\hline 3 & Leads to washing away of soil nutrient & $104 *(71.72)$ & $1 *(0.70)$ & $40 *(27.58)$ & 2.44 \\
\hline 4 & Decreases farm income & $21 *(14.79)$ & $28 *(19.66)$ & $93 *(65.55)$ & 1.49 \\
\hline 5 & Increases cost of production & $2 *(1.40)$ & $51 *(35.93)$ & $89 *(62.67)$ & 1.38 \\
\hline 6 & Reduces crop growth & $117 *(78)$ & $30 *(20)$ & $3 *(2)$ & 2.76 \\
\hline 7 & Leads to death of livestock & $60 *(46.87)$ & $26 *(20.32)$ & $42 *(32.81)$ & 2.14 \\
\hline 8 & Reduces value of farm output & $107 *(75.35)$ & $28 *(19.72)$ & $7 *(4.93)$ & 2.70 \\
\hline 9 & Increases pest infestation & $9 *(5.56)$ & $66 *(40.74)$ & $87 *(53.70)$ & 1.59 \\
\hline & Total Mean (X) & & & & 19.63 \\
\hline & Grand Mean $(\mathrm{X})$ & & & & 2.18 \\
\hline
\end{tabular}

Source: Field Survey.

*Multiple responses

Figures in parenthesis are percentages

Table 3. Regression analysis on the perceived effect of environmental hazard on agricultural production

\begin{tabular}{ccccc}
\hline Variable & Double log & Semi-Log & Exponential & Linear \\
\hline Constant & 4.074 & 88.826 & 4.873 & 132.634 \\
& $(11.945)^{* * *}$ & $(7.036)^{* * *}$ & $(21.784)^{* * *}$ & $(13.246)^{* * *}$ \\
Flood & .111 & -1.037 & -.159 & -9.498 \\
& $(.355)$ & $(-.089)$ & $(-1.638)$ & $(-2.194)^{* *}$ \\
Oil Pollution & -.512 & -18.467 & -.184 & -8.708 \\
& $(-1.612)$ & $(-1.569)$ & $(-1.933)$ & $(-2.049)^{* *}$ \\
Erosion & -.852 & .37 .944 & -2.45 & -11.584 \\
Wind storm & $(-3.544)^{* * *}$ & $(-4.265)^{* * *}$ & $(-3.555)^{* * *}$ & $(-3.775)^{* * *}$ \\
$\mathrm{R}^{2}$ & -.437 & -5.613 & -.303 & -8.077 \\
$\mathrm{R}^{-2}$ & $(-1.550)$ & $(-.537)$ & $(-3.971)^{* * *}$ & $(-2.371)^{* *}$ \\
F-RATIO & 0.615 & .745 & .695 & .715 \\
\end{tabular}

Source: Field survey.

Note: *** Significant at $1 \%$.** Significant at 5\%.* Significant at $10 \%$ 
3. Analysis of respondents perceived effect of environmental hazard on agricultural production

Multiple regression analysis was used to analysis the relationship between environmental hazard and agricultural output. The variable for environmental hazard included windstorm, flood, erosion and oil pollution. These were measured based on their number of occurrences. Log Linear functional form was chosen as the lead equations for effects of environmental hazard on agricultural production among respondents. This was based on the number of significant variables, magnitude of the coefficient of multiple determination $\left(\mathrm{R}^{2}\right)$ and the signs of the significant variables conforming to a priori theoretical expectations. The linear $\log$ function had five significant variables with $\mathrm{R}^{2}$ value of 0.715 which shows that $71.5 \%$ of the total variation observed in the dependent variable (agricultural production) for respondents in the study area was accounted for by the independent variables included in the model. The F- value of 17.209 indicated that the model is significant for respondents in the study area.

Flood, oil pollution, erosion and wind storm were significant and negatively related to the agricultural production of respondents in the study area.

Flood was negatively significant at $5 \%$ indicating that as flooding increased in the study area, the quantity of agricultural production reduced. In crop production leaching leads to loss of soil nutrients. Extreme weather conditions such as prolonged drought and excessive amount of rainfall that leads to flood are detrimental to crop production outputs. Etuonovbe ${ }^{12}$ observed that livestock production is negatively affected by flood due to increase in pests and diseases leading to high mortality. This effect is definitely not wholesome for agriculture because it will be a loss not only to the farmlands and livestock but also to human life and other property, and knowing the impoverished nature of the rural farmers, the effect will not only drive them out of business, as most of them will also lose almost all they have that will help them survive. Adeleye and Rustum ${ }^{13}$ reported cases torrential rains pushing rivers over their banks and washing away livestock in Lagos state.

Oil pollution was negatively significant at $5 \%$. This entails that as incidences of oil pollution increased in the study area, agricultural production reduced. In the process of oil exploration, lands are acquired where pipeline terminals and platforms are sited.

Erosion was negatively significant at $1 \%$. This indicated that as the washing away of the soil surface increased in the study area, there was reduction in agricultural output. Abegunde et $a l^{14}$ reported that soil erosion in the South-eastern part of Nigeria has been identified as the most threatening environmental hazards in the country

Windstorm was negatively significant at $5 \%$. Increase in windstorm in the study area has led to decrease in agricultural output. This could be attributed to the damages done to pollen grains and fruits during storms. This leads to decrease in harvest of fruits and crops with appreciable market values. Also, windstorm can lead to loss in livestock and other farm damages.

\section{Conclusions}

This paper has evaluated environmental hazard as a critical issue affecting agricultural production of rural households in Imo State, Nigeria. The study has brought to limelight the fact that environmental hazard affects agricultural production and that respondents were relatively aware of these effects. Flood, oil exploration activities, erosion and windstorm had significant negative relationship with agricultural production in the study area.

Based on the findings, the following recommendations are made to mitigate the effects of environmental hazards on agricultural production and on rural dwellers:

Effort should be made to diversify agricultural production activities in the rural areas. This is because the rural households depend mainly on agricultural production and diversification will aid in cushioning the effects of risks arising from environmental hazards. Insurance schemes should be provided for farmers and compensations paid to them over losses arising from environmental hazards.

Companies that engage in oil exploration activities in Imo State (Addax, Chevron, Shell, Nigeria Agip etc) should be alive to their corporate social responsibility towards host communities whose environment is devastated by their activities.

Extension agencies in Imo State should intensify efforts aimed at inculcating healthy agricultural practices and environment preservation.

\section{REFERENCES}

[1] United Nations Environment Programme (UNEP) State of the Environment and Policy Retrospective: 1972-2002. UNEP. (2010). http://www.unep.org/geo/GEO3/english/081.htm .Retrieved $12 / 10 / 2014$

[2] Kirkhorn, S. Partners in Agricultural health: Agricultural respiratory Hazards and diseases: A primer for Wisconsin Practitioners and health/ safety professions Waseca; $\mathrm{MN}(2010)$.

[3] Morton, J. The impact of climate change on small holder and subsistence agriculture. Proc. National Academic Science, USA(2007). Vol. 204 pages 19680-19685

[4] Thorlackson, T. and Neufelt, H. Reducing Subsistence Farmers' Vulnerability to Climate Change: Evaluating the Potential Contributions of Agro Forestry in Western Kenya: Journal of agriculture and food security. (2012).

[5] United Nations Development Programme (UNDP) Disasters and the Environment: Disaster Management Training Programme. (1995). www.eoearth.org/article/. Retrieved $21 / 10 / 2013$ 
[6] Izuogu C.U, Atasie Chikerenma and Ifenkwe G.E Perceived Effects of Environmental Hazard on Health Conditions of Rural Farm Households in Imo State, Nigeria. International Journal Of Advanced Research in Engineering \& Management (IJAREM). (2015): Vol. 01 Issue 04 July 2015 26

[7] Izuogu C.U and Ekumankama O.O: Assessment of Rural Infrastructures and Productive Assets Provided by Fadama 11 Development Project in Okigwe Agricultural Zone of Imo State, Nigeria. International Journal of Academic Research in Business and Social Sciences June 2015, Vol. 5, No. 6 ISSN: 2222-6990

[8] Ifenkwe, G. E. and Izuogu, C. U. Rural Household's Perception of Environmental Hazards in Imo State, Nigeria. International Journal of Applied Research and Technology. (2015). 4(6): $32-38$

[9] Ifenkwe G.E Food safety regulations: reducing the risk of food borne diseases in rural communities of Abia state, Nigeria. Agricultural Science Research Journals Vol. 2(7), pp. 384-389, July 2012 ISSN-L:2026-6073 Available online at http://www.resjournals.com/ARJ. (2009): Retrieved December 15, 2014
[10] Sanni, O.O, Onadipe, P., Mussagy M.D, Abass A: Successes and challenges of cassava enterprises in West Africa: a case study of Nigeria, Bénin, and Sierra Leone. International Institute for Tropical Agriculture (IITA) (2009):

[11] Echebiri, R. N and Edaba M.E. I: Production and Utilization of Cassava in Nigeria: Prospects for Food Security and Infant Nutrition. PAT 2008; 4 (1): 38-52: ISSN: 0794-5213.www.patnsukjournal.com/current issue. Retrieved $25 / 10 / 2014$

[12] Etuonovbe Angela Kesiena: The Devastating Effect of Flooding in Nigeria. www.fig.net/pub/fig2011/ts066. Retrieved 17/10/2014

[13] Adeleye, A. and Rustum R, Lagos (Nigeria) Flooding and Influence of Urban Planning. Journal of Urban .Design and Planning (ICE), 164(3): (2011).175-187.ISSN:1755-0793, E-ISSN: 1755-0807.

[14] Abegunde A.A, Adeyinka S.A, Olawuni P.O and Oluodo A.O An Assessment of the socio economic impacts of soil erosion in South Eastern Nigeria. TS 56- Special Valuation Situations. Shaping the Change XXIII Congress Munich, Germany (2011) 